\title{
Research on the Optimization of Capital Structure of X Company
}

\author{
Zihan Gong ${ }^{1}$ \\ ${ }^{1}$ Harbin Cambridge College, Business Administration, Harbin, China, 150000 \\ E-mail: $1908835918 @ q q . c o m$
}

\begin{abstract}
The formation of enterprise capital structure comes from various financing ways of enterprises, and the composition types of different financing ways determine the capital structure of enterprises. The key to the sustainable development of enterprises is the appropriate capital structure, so the capital structure, to a large extent, affects the solvency and refinancing ability of enterprises, and is an important indicator related to the financial status of enterprises. This paper will make further analysis from X Company's equity structure, debt structure and financing structure.
\end{abstract}

Keywords: Capital structure, Influencing factors, Optimization scheme

\section{INTRODUCTION}

As for the research on capital structure, foreign scholars are more substantial in theory. On the basis of considering risks, they evaluate the capital structure by constructing mathematical models and put forward corresponding improvement measures. Meanwhile, they fully study the capital elements and risk issues and put forward the existence of default cost and bankruptcy cost. These contents are very worth learning. Although Chinese scholars started to study capital structure relatively late, they have found the capital structure theory and method suitable for domestic enterprises with their unremitting efforts. Scholars use regression analysis to evaluate the influencing factors of capital structure and propose that the main indicators affecting capital structure are the size and growth of the company. Moreover, they have made more extensive research on the structure of debt and the financing methods of equity structure.

The research of most scholars remains at the basic theoretical level. Even when considering the mathematical model, the model cannot be fully used to evaluate the optimal capital structure of the whole industry or among different industries due to the relatively many relevant restrictive conditions. Therefore, for better analysis, this paper combines the static optimal structure for dynamic analysis. At the same time, in order to comprehensively evaluate the influencing factors of capital structure, this paper takes both macro factors and micro factors into the scope of the investigation.

On the optimization of capital structure, foreign research is more extensive and in-depth. However, because the history of China's factors and the development background of listed companies is different from abroad, many Chinese listed companies by state-owned enterprise restructuring, the processing of the capital structure and the influence factors of the capital structure need to be combined with the specific factors for analysis. Chinese long-term financing preference is equity financing of listed companies and this is obviously inconsistent with overseas financing structure theory. Therefore, it is of special significance to study the financing preference of Chinese listed companies for the optimization of the capital structure of domestic enterprises.

\section{THEORIES RELATED TO CAPITAL STRUCTURE}

Generally speaking, capital structure refers to the ratio of debt capital and equity capital of an enterprise. For an enterprise, the optimal capital structure is the lowest weighted average cost of capital and the highest enterprise value. However, the feasibility of this standard in practice is questionable. Because under normal circumstances, a certain degree of debt is conducive to reducing the cost of capital of the enterprise, and more debt will inevitably increase the 
financial risk of the enterprise. Therefore, the problem of enterprise capital structure is the ratio of debt capital of the enterprise in general and is the appropriate proportion of debt capital in the total capital of the enterprise.

Foreign scholars have roughly studied the influence of four factors on the capital structure. The first is the influence of macro factors on the capital structure. Mazur K.(2017) concluded through research and comparison that the factors affecting the capital structure of the same type of companies with the same development characteristics or enterprise characteristics have little difference, mainly including operating conditions, assets and other factors. The second is the influence of micro factors on capital structure: Amir Moradi and Elisabeth Paulet (2018) studied the influence of their own factors on the formation of capital structure of companies in 559 European countries during the period from 1999 to 2015. Studies have found that economic growth, profitability, tax protection and the impact of the euro crisis are significantly negatively correlated with leverage ratio and debt-equity ratio, and significantly positively correlated with return on equity [1]. Thirdly, as for the impact of research methods on capital structure, Markus and Jerome et al. (2017) respectively analyzed and studied the impact of seven types of negative and positive factors on capital structure. The results show that there is a positive correlation between tangible assets and the leverage ratio of capital structure. The value of the intangible capital market and corporate profits have a negative impact on the structure of intangible capital, and these three main factors have a significant impact on the company's capital structure [2]. The fourth is the impact of the research perspective on the capital structure: Oyilik Peterson and Olayinkauadiale (2017) focused on discussing whether the concentration of capital in ownership income directly affects the profitability of banks in the context of developing countries. The researchers found that commercial banks with high-yielding concentrated equity have relatively high returns on strategic assets, while commercial banks with dispersed ownership have relatively low returns on strategic assets. [3].

Chinese scholars also study capital structure from four perspectives. The first perspective is to analyze the influencing factors of capital structure. Liu Shunqi (2018) takes listed companies as an example to analyze the causes of capital structure. First of all, managers make decisions based on their own interests, which will lead to the decrease of enterprise value and the decrease of resource allocation rate. Secondly, the imperfect financing system leads to the unsatisfied demand for funds and financing preference[4]. The second perspective is to analyze the financing and dividend distribution of listed companies. Cui Can (2019) found through studying the financing behavior of listed companies in China that listed companies have a high dependence on external financing, resulting in less internal financing. By analyzing the causes of this phenomenon, it is proposed that the equity system should be improved to appropriately raise the cost of equity financing, and at the same time, the perfection of the bond market and the improvement of the credit risk system should be promoted, so as to improve investors' confidence in enterprises [5].The third Angle is to discuss the practical significance of capital structure optimization: Lu Haijun (2019) studied the capital structure with big data as the background, and pointed out that the governance level of the enterprise needs to be improved, which leads to the contradiction and interest conflict between the shareholders and the management of the company, reduces the profit of the company, and then increases the cost of capital structure improvement. [6].The fourth perspective is to analyze the effect of leverage: Chen Yi (2018) analyzed the role of financial leverage in adjusting capital structure, emphasized that finding the critical point of financial leverage makes the capital structure optimal, and proposed the main problems of enterprise capital structure. Enterprises blindly borrow in order to expand the scale of operation, resulting in excessive debt ratio. Listed companies prefer equity financing, which leads to too low debt ratio and loss of leverage. The capital structure is inelastic so that it cannot be converted and adjusted in time when the company is in trouble [7].

Today's net income theory, net operating income theory and traditional tradeoff theory are formed by the early capital structure theory. However, these three theories have not been tested by actual statistical analysis, so these theories have not been accepted by the public. Modern capital structure theory with tradeoff theory as the apex has further expanded the external factors that can affect the capital structure. Enlarging the connotation of the cost of capital, when the introduction of bankruptcy cost and tax, the company will have an optimal capital structure. Then, the new capital structure theory, which is called the analytical framework of information misallocation, appears, and introduces individual behavior motivation to make it related to modern information economics, thus forming the theory of signal transmission and control power. By introducing the normative research and empirical research methods of information economics, the research direction is focused on the internal factors of enterprises. This research method follows the hypothesis of modern capital structure theory. The further exploration of the hypothesis of sufficient information opens up a new way to seek the development of capital structure theory. The theory of preferential financing fully explains how companies choose tools to reduce financing costs when internal managers and external investors have asymmetrical grasp of financial information of companies. 


\section{CURRENT SITUATION OF $X$ COMPANY}

\subsection{Company Profile}

X company was established in January 1993. As a domestic enterprise integrating large-scale fishing industry and trade as well as production, education and research, the economic benefits of $\mathrm{X}$ Company have been among the best in the same industry in the province and even the country for many years. $\mathrm{X}$ company has successively won the honorary titles of national township enterprises with the best economic benefits, the National Top Ten enterprises in export business of township enterprises, and the national key leading enterprises in agricultural industrialization.

With the goal of "creating first-class brand with first-class quality and building Oriental Food City", X Company has taken the initiative to meet international standards in management. It has passed ISO-9000 quality management system and FDA certification in the United States and obtained HACCP certification. The company attaches great importance to product development and quality. They have established a provincial enterprise technology center with food research institute, independent research and development of more than 300 varieties of " $\mathrm{X}$ " brand food. The production capacity is 100,000 tons per year and it is China's important green food production base and export base.

\subsection{Current Situation of Capital Structure of the Company}

In fact, capital structure is the ratio between liabilities and assets, as well as the composition of the structure and source of debt and the source and composition of equity. From the perspective of the concept of capital structure in the broad sense, the asset-liability ratio can basically represent the capital structure of an enterprise as a whole.

\subsubsection{Analysis of Ownership Structure}

In fact, the analysis of ownership structure is to analyze the relationship between the shareholding ratio and the nature of shareholders. Researchers can judge whether a company is dominated by one shareholder based on the degree of equity checks and balances, which is an indispensable part of equity structure analysis.

For the analysis of ownership structure, the first thing is the degree of ownership concentration. A measure index of ownership concentration is the shareholding ratio of the largest shareholder, and the shareholding ratio of the largest shareholder is an important standard to judge ownership concentration.
Through the analysis of the shareholding ratio of $\mathrm{X}$ Company, it can be seen that the shareholding ratio of state-owned asset management companies is higher than $40 \%$ in the past five years. Although there is little change, the shareholding ratio of state-owned asset management companies is on the decline on the whole. Although the state controlling proportion does not reach more than 50\%, the second largest shareholder holds 3\% of the shares, while other shareholders hold a smaller proportion. There is a huge gap in the shareholding ratio among shareholders. The state shares have absolute control over the shares of $\mathrm{X}$ Company, and the shareholding is highly concentrated. The measure of equity checks and balances is to calculate the ratio of the shares held by the largest shareholder and the second to five shareholders of a company. Through calculation, it is found that the shareholding ratio of the largest shareholder occupies a very high proportion in the total shareholding ratio of the top ten shareholders, accounting for more than $80 \%$. Through the analysis of the equity balance degree and the shareholding ratio of the top ten shareholders, it can be concluded that the state shares occupy an absolute advantage in $X$ Company, and the state-owned assets management company controls the production and operation of the enterprise, which may lead to a series of problems caused by the lack of supervision.

\subsubsection{Financing Structure Analysis}

Financing ways for enterprises are divided into internal financing and external financing. Endogenous financing is the enterprise of retained earnings and depreciation of fixed assets. External financing mainly includes the enterprise issuance of stocks, bonds, bank loans. X company applies various financing channels of information obtained by calculation of assets and the proportion of total assets with an average of $17 \%$ of internal financing. External financing in the proportion of debt financing is approximately $58.58 \%$ and is the main financing way of $\mathrm{X}$ with the proportion of equity financing about $36 \%$. In terms of equity financing, since the listing of X Company, except the initial issue, one rights offering has been carried out. In terms of debt financing, the main financing method used by $\mathrm{X}$ Company is bank loan. Therefore, in terms of financing, $\mathrm{X}$ Company first considers debt financing, followed by equity financing. It can be seen that $\mathrm{X}$ does not make full use of internal financing and has a high debt preference.

\subsubsection{Debt Structure Analysis}

The significance of debt structure is the relation between the ratio and quantity of various components of enterprise debt. If the collocation of various components is unreasonable, the possibility of debt crisis will be increased. When analyzing debt structure, we can start 
from debt maturity. The purpose of analyzing debt maturity is to investigate whether enterprises prefer long-term debt or short-term debt when conducting debt financing, and then analyze whether enterprises face financial risks and repayment pressure according to debt maturity structure. This paper analyzes whether the proportion between the interest-free and interest-bearing liability of the enterprise is relatively reasonable, so as to further understand the reasons for the high asset-liability ratio.

\section{SPECIFIC PLAN FOR THE OPTIMIZATION OF THE COMPANY'S CAPITAL STRUCTURE}

\subsection{Adjust the Debt Structure of Enterprises}

\subsubsection{Use of Finance Lease}

Enterprises can sell part of inefficient fixed assets or idle assets, use the proceeds from the sale to pay off debts and turn some highly professional fixed assets into financing leased fixed assets. Financing lease can reduce corporate debt ratio and reduce business costs, because of the payment for fixed assets. At the same time, the flow ratio in the corporate debt structure of $\mathrm{X}$ company is too high and did not make full use of interest-free liabilities. The total proportion is higher. Asset-liability ratio and high debt level will company bad message to the outside world, which leads to increase the cost of financing. The enterprise's own debt service pressure will be higher, financial risk also will rise, and the market value of the enterprise will therefore decrease. Therefore, in order to optimize the capital structure of enterprises from the perspective of debt, the debt ratio should be first reduced so that enterprises form a reasonable debt scale.

The depreciation amount of fixed assets used for financing lease can be deducted before tax, and the enterprise can further reduce the asset-liability ratio.

\subsubsection{Increase the Proportion of Long-term Borrowing}

By means of asset securitization and non-public stock, enterprises achieve long-term liabilities. The company's long-term borrowing can be set to different period and the longer the loan time limit promised, the higher interest rates. This approach can increase the proportion of long-term loans and to a certain extent, reduce short-term debt service pressure. Then long-term loan return on investment to higher long-term projects, making full use of the potential capital. Although the interest rate paid by this approach may be higher than the short-term debt, the return funds of long-term projects can be used to compensate for the higher interest rate, and the extension of the term of use of funds is very beneficial to the stability of the enterprise's capital structure.

\subsubsection{Use Commercial Credit}

The company should continue to adjust the debt structure, increase commercial credit, maintain a good relationship with the upstream and downstream of the supply chain, and try to avoid the borrowing of a large amount of bank loans. It can increase the proportion of accounts payable to long-term strategic partners and the proportion of accounts payable to related parties that are not within the scope of merger so that the company can have more working capital turnover or make long-term investment, which is conducive to the improvement of the company's debt structure.

\subsection{Expand Financing Channels}

The financing channels of X Company are relatively simple, most of which are bank loans, and few are financed by bills and bonds, and the interest-bearing liability ratio reaches $65 \%$. Bank borrowing is the most important way of external borrowing financing. From the perspective of tax burden, the order of corporate borrowing from the outside is issuing bonds, borrowing from financial institutions and issuing stocks. From the perspective of flexibility, the order of external borrowing is that financial institutions borrow money, issue bonds and issue stocks. According to the specific situation of X Company, the following optimization schemes are mainly proposed.

\subsubsection{Asset Securitization}

The method of asset securitization is adopted to securitize the future cash flow of some assets with economic potential in the enterprise, and quickly convert the assets with poor liquidity into cash, which can be invested in the development of the company. $\mathrm{X}$ Company can reduce financing costs by providing redemption guarantee of a certain proportion for securitized assets, providing third-party guarantee and other measures to attract more investors.

\subsubsection{Introduce Investment from Financial Institutions}

In order to solve the problem of capital demand, the company can choose to invest in financial institutions. Generally, investing in longer holding period, financial institutions can effectively control financial risks. In addition, financial institutional investors will provide supervision and suggestions on the use of funds, which can effectively improve the use efficiency and operation ability of the company's funds. 


\subsection{Optimize the Company's Ownership Structure}

At present, the largest shareholder of X Company holds more than $40 \%$ of the shares, which is excessively concentrated, presenting a situation of "one dominant share" of state-owned shares. The following suggestions are proposed for the optimization of the ownership structure: To reduce state holding ratio to $30 \%$, the management holding ratio of $10 \%$, the financing institutional investors hold a ratio of $15 \%$, while the country is still the first big shareholder, but professional institutional investors have more power.

The management department dispatches personnel to manage $10 \%$ of the shares held by the employees. Shares of the Company must be traded among internal employees, and it is not allowed to sell shares of the Company to anyone other than employees without authorization.

\section{CONCLUSION}

In actual production, enterprises will face the problems of whether the capital structure is reasonable and whether it is beneficial to the sustainable operation of the enterprise. The capital structure has a profound impact on the business performance of the enterprise. After the capital structure analysis of X Company, the following conclusions are drawn:

The problems of enterprise capital structure lie in the high asset-liability ratio, the high proportion of current liabilities, the single financing channel and the high concentration of ownership. The factors that affect the capital structure of an enterprise include the external environment and the operating conditions of the company itself, but the influence of the company's own factors is greater. Through the above analysis and research process, the specific plan and safeguard measures for capital structure optimization of $\mathrm{X}$ Company are obtained:

(1) Adjust the debt structure of enterprises

(2) Expand financing channels

(3) Optimize the ownership structure of the company

(4) Strengthen self-accumulation

The capital structure involves a very wide range of content. Many domestic and foreign experts have carried out relevant theoretical research, which involves a lot of knowledge points. This paper is only a case study, which may have some inspiration to other enterprises, but has no practical significance.

The optimization of capital structure has always been worth in-depth discussion. The industry and life cycle of an enterprise will have an impact on the change of capital structure. According to X company obtained nearly five years of data calculation of the optimal capital structure interval, the determination of capital structure interval has a certain significance in changing the company internal and external environment. The company still needs to constantly adjust the capital structure according to actual condition and this is the place where the future needs to continue to study.

\section{ACKNOWLEDGMENT}

Time flies, the two-month project has been finished, and my paper writing has been finished. However, the smooth completion of the paper cannot be achieved without the help of teachers, so I would like to express my gratitude to them again. First of all, I would like to thank my thesis supervisor. The so-called good in the teaching, teaching in the teacher, in the process of writing the teacher can always guide my direction from a professional point of view, listen to your words, win ten years. So, I want to thank my mentor from the bottom of my heart. Second, I would like to thank my subject research teacher. It is she who gives us knowledge and answers our doubts on the platform of three feet. With all her resources, she has laid a solid professional foundation, cultivated my ability and broadened my horizon. Here, I would like to express my sincere thanks to my teachers.

\section{REFERENCES}

[1] Amir Moradi , Elisabeth Paulet. The Firm-specific Determinants of Capital Structure-AnEmpirical Analysis of Firms before and during the Euro Crisis[J].Research in International Business and Finance, 2018(2):324-325.

[2] Markus.Hang, Jerome, Geyer-Klingeberg.Measurement matters-A mata-study of the deter-minants of corporate capital structure $[\mathrm{J}]$. The quarterly review of economicsan-d finance, 2017(11):67-69.

[3] OYiliK Peterson, Olayinka Uadiale.Ownership Concentration and Bank Profitability[J].F-uture Business Journal， 2017， 25(7):67-89.

[4] Liu Shunqi. The capital structure optimization of China's listed companies [J]. Modern Enterprises,2018, (8) :102-103.

[5] Cui Can. Analysis of Capital Structure and Financing Behavior of Chinese Listed Companies [J]. Brand Research,2019, (17) :25-27.

[6] Lu Haijun. Corporate Governance and Dynamic Adjustment of Capital Structure in the Context of Big Data [J]. Shopping mall modernization,2019,(24) : 107-108.

[7] Chen Yi. Research on the Capital Structure Optimization Based on the Perspective of Financial Leverage Effect [J]. Journal of Hunan Posts and Telecommunications Industry Vocational and Technical College,2018, (2) :89-91. 